\section{HSE}

Historia Social y de la Educación

Social and Education History
Hipatia Press

www.hipatiapress.com

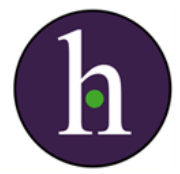

Instructions for authors, subscriptions and further details:

http://hse.hipatiapress.com

\title{
Budapest building managers and the Holocaust in Hungary
}

Helena Prieto ${ }^{1}$

1) Universitat de Barcelona (España)

Date of publication: February $23^{\text {rd }}, 2018$

Edition period: Edition period: February 2018-June2018

To cite this article: Prieto, $\mathrm{H}$. (2018). Budapest building managers and the Holocaust in Hungary [Review of the book]. Social and Education History 7(1), 97-99. doi: 10.17583/hse.2018.2760

To link this article: http://dx.doi.org/10.17583/hse.2018.2760

\section{PLEASE SCROLL DOWN FOR ARTICLE}

The terms and conditions of use are related to the Open Journal System and to Creative Commons Attribution License (CC-BY). 


\section{Reviews (I)}

Pal Adam, I. (2016). Budapest Building Managers and the Holocaust in Hungary. Budapest (Hungary): Palgrave Macmillan.

7 he main purpose of the research of Istvan Pal Adam, author of Budapest Building Managers and the Holocaust in Hungary, is to 1 push the reader into a different and less obvious approach to the atrocious Holocaust committed by the Nazis during the III Reich, in the first half of twentieth century. Pal Adam, a Hungarian researcher with extended experience in Holocaust research, introduce us to a scenario close by focusing on the following questions: what role did the building managers and concierges -in Hungarian: the házmester- have during this critical period? Did they perpetrate this inhumane episode of European History or instead contribute to survival of the Jewish Hungarian community? In this study the reader is invited to explore the ideas through the evidences presented in this work in order to reach beyond the first-order categorization of "perpetrator", "bystander" or "rescuer". Instead of focusing on the belligerent conflicts that surrounded the Holocaust, which is the approach taken in the vast majority of Holocaust's studies, Pal Adam alludes to the lives stories of the házmester in Budapest along the first two chapters of the book. These provide the reader with a much richer understanding of the reasons behind the actions of the házmester. The author traces further back the emergence of the metropolis in the center of Budapest, and the subsequent increase of the number of házmester present in the area. At the beginning of the century, being a concierge was conceived as a part-time job with a modest income, but both industrialization and rapid urban development readily changed that. The role of the házmester become even more central when authorities started to enroll concierges as their main 
HSE - Social and Education History Vol. 7 No. 1 February 2018 pp. 97-99

sources of information regarding citizens and the life of the community: building managers were reliable sources of information about the tenants in their buildings, in particular being able to provide their date and place of birth, religion, names of their relatives and how long they would be in the building. In fact, házmester were assumed to be able to provide such information and could otherwise be fined by the authorities inasmuch as it was the main key of the ghettoization. This lead to a turning point in the history of the házmester: deciding whether to help or not the 225.000 prosecuted people in the period between March 1944 and February 1945. How did the házmester react to the irruption of anti-Jewish laws? In the course of the chapters three to five, Pal Adam brings us closer to the reality of that moment: early in the summer of 1944 a dispersed ghetto came to form in the center of Budapest and the safety of its members laid, in great measure, in the hands of the building managers. Indeed, during the creation of ghettos the attitude of the házmester varied in a wide range. Regardless of their choice, a mere passive behavior was certainly not viable since they were known to have information and the authorities repeatedly inquired them; thus the decision was forced upon them, either hiding the names of residents to the police as a protective measure against the ghetto discrimination - which translated into moving to the Yellow Star houses - or instead supply the information on Jewish residents to the authorities, which consequently implied that these residents would be deported to Nazi German concentration camps. The different actions taken by the házmester were later to be highlighted, once the Second World War ended, during the Justificatory Committee held after the liberation of Hungary. This is detailed in the book starting at the sixth chapter. In this last chapter, the reader find out how the Justificatory Committee called the building managers to account to be judged according their actions during the prewar and Nazi occupation. 
The large amount of evidences and the accurate work done in this study is the key element of the narration of an extremely hard episode of European story. The evidence-based method Palm uses allows the reader vibe with the crudeness of the lives stories included in the book with the rigor that characterized them. Definitely, this study can attract historian and educational researchers as well as any non-expert people in those disciplines

Helena Prieto

Universitat d'Andorra

hprieto@uda.ad 